Sains Malaysiana 50(4)(2021): 1027-1036

http://doi.org/10.17576/jsm-2021-5004-13

\title{
Food Poisoning Outbreaks among Schoolchildren in Terengganu and their Associated Factors
}

(Wabak Keracunan Makanan dalam Kalangan Pelajar Sekolah di Terengganu dan Faktor Penyumbangnya)

\author{
Nur Baizura Aini AbDullah \& Ahmad Filza Ismail*
}

\begin{abstract}
Food poisoning is a public health problem in Malaysia and among the top five communicable diseases in Malaysia. This study aimed to determine the proportion of food poisoning cases involving schoolchildren in Terengganu in 2016 and their associated factors. This was a cross-sectional study using secondary data collected from 21 food poisoning outbreaks among schoolchildren in Terengganu in 2016. The proportion of food poisoning outbreaks involving schoolchildren in Terengganu in 2016 was $63.6 \%$. Ministry of Education (MOE) school had contributed to $95.3 \%$ of outbreak cases, $81 \%$ occurred at secondary school and $57.1 \%$ involved school located in urban district. Poultry $(61.9 \%)$ was the most common food vehicle, and Salmonella spp. (52.4\%) was the most common microbial etiological agent. Urban district schools had the adjusted odds $(a O R=1.803 ; 95 \%$ CI: 1.435,2.267; $p<0.001)$ compared with rural district schools. Non-MOE schoolchildren were more likely to be involved in school food poisoning (aOR=4.439; 95\% CI: 2.690,7.177; $p<0.001)$ compared with MOE schoolchildren. Moreover, egg consumption was 4.6 times (aOR=4.627; 95\% CI: 1.779,12.035; $p=0.002)$ more likely to be associated with school food poisoning outbreaks in Terengganu in 2016 compared with rice consumption. Cross-contamination ( $a O R=0.445 ; 95 \%$ CI: $0.445,0.231 ; p=0.015)$ was less likely to be linked to school food poisoning compared with inadequate cooking and reheating. Food poisoning among schoolchildren in Terengganu has been associated with non-modifiable factors, such as school district location, and modifiable factors, such as food vehicles and critical control points. Health education on food safety, food handling, strict hygiene practice and clean canteen environment need to be strengthened.
\end{abstract}

Keywords: Foodborne disease; food poisoning outbreak; schoolchildren

\section{ABSTRAK}

Keracunan makanan adalah salah satu masalah kesihatan awam dan antara lima penyakit berjangkit utama di Malaysia. Kajian ini adalah untuk menentukan perkadaran kes wabak keracunan makanan yang melibatkan pelajar sekolah di Terengganu pada tahun 2016 dan faktor yang berkaitan dengannya. Kajian ini dilakukan dengan kaedah hirisan lintang menggunakan data sekunder kejadian wabak keracunan makanan yang melibatkan pelajar sekolah di Terengganu pada tahun 2016. Perkadaran kejadian wabak keracunan makanan yang melibatkan pelajar sekolah di Terengganu tahun 2016 adalah 63.6\%. Sekolah di bawah kelolaan Kementerian Pelajaran Malaysia (KPM) menyumbang kepada 95.3\% kes keracunan makanan dengan sekolah menengah menyumbang kepada $81 \%$ kes dan $57.1 \%$ berlaku di sekolah yang terletak di kawasan bandar. Ayam (61.9\%) adalah jenis makanan yang tertinggi menyumbang kepada kejadian wabak keracunan makanan di sekolah dan Salmonella spp. (52.4\%) adalah agen etiologi mikrob yang paling kerap dijumpai. Sekolah yang terletak di kawasan bandar (aOR=1.803; 95\% CI: 1.435, 2.267; $<$ <.001) dan pelajar sekolah di bawah kelolaan bukan KPM (aOR=4.394; 95\% CI: 2.690,7.177; $p<0.001)$ mempunyai risiko lebih tinggi untuk mengalami wabak keracunan makanan berbanding dengan sekolah di bawah KPM. Di samping itu, pelajar yang memakan telur adalah 4.6 kali (aOR: 4.627; 95\% CI: 1.779, 12.035; $p=0.002$ ) lebih berisiko untuk terlibat dengan wabak keracunan makanan di sekolah jika dibandingkan dengan nasi atau bijirin. Pencemaran silang (aOR =0.445; 95\% CI: 0.445.0.231; $p=$ 0.015) mempunyai risiko yang lebih rendah berbanding risiko memakan makanan yang tidak dimasak sepenuhnya atau suhu pemanasan makanan yang tidak mencukupi. Keracunan makanan dalam kalangan pelajar sekolah di Terengganu adalah berkaitan dengan faktor seperti lokasi sekolah, jenis makanan dan titik kawalan kritikal semasa penyediaan makanan. Pendidikan kesihatan perlu diperkukuhkan dalam aspek keselamatan makanan, pengendalian makanan, amalan kebersihan yang sempurna dan persekitaran kantin yang bersih semasa penyediaan makanan.

Kata kunci: Pelajar sekolah; penyakit bawaan makanan; wabak keracunan makanan 


\section{INTRODUCTION}

In 2014, the World Health Organization (WHO) reported that $3 \%$ of two million deaths each year, including among children, were attributed to diarrhoeal diseases. In Malaysia, food poisoning is a longstanding public health issue, with an incidence rate of $44.18 / 100,000$ population in 2010,50.42/100,000 population in 2014 and $47.2 / 100,000$ population in 2016 , and a mortality rate of $0.041 / 100,000$ population in 2016 (MOH 2016). The school food poisoning incidence rate remained practically unchanged at $49.2 \%$ for 2013 and $49.1 \%$ for 2014, although many steps have been taken to reduce this rate (MOH 2014). According to the National Health and Morbidity Survey III (NHMS III), the overall incidence of self-reported acute diarrheal illness within two weeks among Malaysians is 5.0\% (95\% CI: 4.8-5.2) or 1,036,518 episodes. Among children, the highest incidence is registered by teenagers aged $15-19$ years $(7.7 \%)$, followed by children aged $0-4$ years $(4.5 \%)$ and $5-9$ years $(3.4 \%)$. Acute diarrhoea is associated with $27.7 \%$ of school absenteeism among students aged 10-19 years. Among the factors restricting the activities of schoolchildren aged 8-9 years, diarrhoeal symptoms have been identified as the most significant (IPH 2008).

A study by Meftahuddin (2002) showed that $66.5 \%$ of food poisoning outbreaks occur in primary and secondary schools, followed by other educational institutions, such as universities, colleges, and training centres. Also uncovered through his study is that only $0.4 \%$ of food poisoning outbreaks originate from contaminated food served at public food courts. These figures indicate that, in the context of food poisoning in Malaysia, schoolchildren are the most likely victims. Food poisoning among students usually stems from consuming food prepared in school canteens, hostel kitchens or under supplementary food programmes. Food poisoning outbreaks in schools are attributed to several factors. Food handlers are the most common contamination source. They can spread harmful organisms through the faecal-oral route or skin lesions. Food contamination is also linked to unhygienic kitchen utensils and counters (Linscott 2011).

The main reasons for school food poisoning outbreaks are: the overly extended period between the preparation and serving of food, the storage of cooked food under an ambient temperature before serving, and cross-contamination (Salleh et al. 2017; Soon et al. 2011). Additionally, higher temperatures in kitchens compared with those in dining areas create an ideal condition for bacterial proliferation. It has also been established that the surfaces of common kitchen items provide favourable breeding grounds for foodborne bacteria. These include the surfaces of cutting boards, wiping cloths, sinks, cleaning sponges, and knives (Abdul-Mutalib et al. 2015).

In schools, poor handwashing practices before meals, and the unavailability of proper handwashing facilities, are the main contributing factors to acute diarrhoea. This coincides with a study by Weaver et al. (2016), which showed that $43 \%$ of students in Myanmar with poor handwashing practices are likely to succumb to bouts of diarrhoea and vomiting. Their study made obvious that the availability of handwashing stations furnished with soap significantly reduced the risk of diarrhoea and vomiting among Myanmar's schoolchildren. It also established that the risk of food poisoning in Myanmar is higher for younger students. This may be due to their low level of immunity against infection, and their lack of responsibility (due to their immaturity) regarding good hygiene practices. However, this situation will probably improve as the students advance in age. Several investigations have shown that schools in rural districts are at higher risk of food poisoning outbreaks. According to a study conducted in India, the main causes of food poisoning outbreaks in rural schools include a poor canteen layout, unsatisfactory sanitary facilities and good hand hygiene practices among food handlers and schoolchildren (Kar 2018).

Between 2012 and 2016, Terengganu registered a rising trend in school food poisoning outbreaks. However, the evidence required for the identification of the most significant aetiological agent, the critical control points (CCPs) and the food vehicles involved, is currently lacking. As such, we aim to determine the proportion of food poisoning outbreaks involving schoolchildren in Terengganu in 2016, and the factors contributing to these outbreaks. The results from this investigation can be used to identify significant food vehicles, aetiological agents and CCPs associated with food handling.

\section{MATERIALS AND Methods}

\section{RESEARCH POPULATION AND DATA COLLECTION}

This was a cross-sectional study done from January to 30 April 2018. This study covered all districts in the state of Terengganu and involved the scrutiny of data obtained from the Terengganu Health State Department. The source populations are represented by the reported food poisoning outbreak cases among schoolchildren (based on the food poisoning outbreak report FWBD/KRM/BG $001-2008$ amendments) in Terengganu in 2016. A total of 2,589 students (643 cases and 1946 controls) involved in 21 food poisoning outbreaks were considered for this study. 
An active case detection activity was performed to find the cases and controls during the food poisoning epidemiological investigations by the Food Safety Quality (FSQ) Unit through interviews, thus enabling a 1:3 ratio for a case-control study. Cases were students with symptoms of vomiting, diarrhoea and/or other acute symptoms associated with the ingestion of food prepared at a school or hostel canteen; a control was defined as anyone who had eaten the suspected food in the school or hostel canteen on the same day of a food poisoning outbreak but showed no symptoms. The inclusion criteria are data on all school food poisoning outbreaks in Terengganu, while the exclusion criteria are school food poisoning outbreaks not involving food prepared at a school or hostel canteen.

\section{RESEARCH TOOLS}

The initial reports on schools involved in food poisoning outbreaks were gathered from the e-Wabak KKM system submitted by the Communicable Disease units of all 8 district health offices in Terengganu. The online system, e-Wabak, was created by the MOH for reporting infectious disease outbreaks in Malaysia. This online system aims to provide an initial outbreak investigation report and to maintain the uniformity of outbreak information accumulated by the Communicable Disease Unit of the Ministry of Health (MOH). e-Wabak also works as a surveillance system for all types of communicable disease outbreaks or clusters in Malaysia.

An e-Wabak report on a food poisoning outbreak includes a descriptive analysis of the food poisoning outbreak and an analytical study done during the outbreak investigations (cohort or case-control study). An e-Wabak report also includes laboratory investigation reports on patient clinical samples, clinical samples of food handlers, including rectal swabs and microbiological analysis of the food handlers' hands, food samples and environmental samples. All the samples are sent for microbiological analysis to find the possible cause of the food poisoning outbreak. Practically, all early reports must be forwarded to the MOH's Communicable Disease Unit using the e-Wabak online system within $24 \mathrm{~h}$ after the notification of any communicable disease outbreak. The final outbreak report must be completed within one month after the outbreak is over.

\section{DATA ENTRY AND STATISTICAL ANALYSIS}

All data obtained were identified by a code number and entered using a checklist proforma enlisting required variables. The confidentiality and protection of the secondary data have been taken into consideration. Every data entry was collected anonymously using a specific identification number. Only researchers had access to the data, and the result did not identify the individual case. Permission to use data had been obtained from the Terengganu State Health Department. SPSS version 24 was used for the entry and scrutiny of the data, while descriptive statistics were used to summarise the subjects' socio-demographic characteristics. Categorical data were presented as frequencies (percentages). Simple and multiple logistic regression modelling were used, to identify the relationship between multiple factors contributing to the occurrence of food poisoning outbreaks in Terengganu in 2016. Variables with p-value $<0.25$, or any clinically important factors from simple logistic regression, were selected to be analysed through the multiple logistic regression model. In multiple logistic regression analysis, variables with p-value $<0.05$ were regarded as significant. Additionally, a potential confounding effect may be present in this study and was controlled by multiple logistic regression analysis.

\section{RESULTS AND DISCUSSION}

PREVALENCE OF SCHOOL FOOD POISONING OUTBREAKS IN TERENGGANU AND THEIR CHARACTERISTICS

In 2016, out of the 33 food poisoning outbreak episodes in Terengganu, 23 (63.6\%) involved schools. However, two episodes were excluded from this study, as they involved food prepared in neither the school nor hostel canteen. This brought the total number of outbreaks investigated to 21 , and these outbreaks occurred in 21 different schools. Table 1 shows the characteristics of school food poisoning episodes in Terengganu. Twenty food poisoning outbreak episodes occurred in schools under the administration of the MOE. These outbreak episodes contributed to $95.3 \%$ of the total school food poisoning outbreaks in Terengganu. Seventeen episodes $(81 \%)$ of food poisoning outbreaks occurred in secondary schools, while 16 episodes $(76.2 \%)$ involved hostel canteens. At $57.1 \%$, the proportion of urban cases was more than that of rural cases. As for the food vehicles involved in food poisoning outbreaks, poultry recorded the highest percentage with $61.9 \%$, while eggs accounted for only $4.8 \%$. At $9.5 \%$, grain and seafood both recorded a $9.5 \%$ proportion of contribution to the food poisoning episodes. Salmonella spp. (52.4\%) headed the list of microbial agents detected in food poisoning episodes, followed by Bacillus cereus $(28.6 \%)$ and Staphylococcus aureus (19.0\%). At 57.1\%, the most common CCP involved in food poisoning outbreaks had to do with inadequate cooking and reheating. Infected food handlers only accounted for $4.8 \%$ of school food poisoning cases. 
TABLE 1. Characteristic of School Food Poisoning Outbreak $(\mathrm{N}=21)$

\begin{tabular}{|c|c|c|}
\hline Variable & No of food poisoning outbreak (n) & Percentage $(\%)$ \\
\hline \multicolumn{3}{|l|}{ School category } \\
\hline Ministry of Education & 20 & 95.3 \\
\hline Non-Ministry of Education & 1 & 4.7 \\
\hline \multicolumn{3}{|l|}{ School type } \\
\hline Primary & 4 & 19.0 \\
\hline Secondary & 17 & 81.0 \\
\hline \multicolumn{3}{|l|}{ Premises type } \\
\hline School canteen & 5 & 23.8 \\
\hline Hostel canteen & 16 & 76.2 \\
\hline \multicolumn{3}{|l|}{ District category } \\
\hline Urban & 12 & 57.1 \\
\hline Rural & 9 & 42.9 \\
\hline \multicolumn{3}{|l|}{ Food vehicles } \\
\hline Poultry & 13 & 61.9 \\
\hline Red Meat & 2 & 9.5 \\
\hline Eggs & 1 & 4.8 \\
\hline Rice/grain & 3 & 14.3 \\
\hline Fish/Seafood & 2 & 9.5 \\
\hline \multicolumn{3}{|l|}{ Microbial agents } \\
\hline Bacillus cereus & 6 & 28.6 \\
\hline Staphylococcus aureus & 4 & 19.0 \\
\hline Salmonella spp. & 11 & 52.4 \\
\hline \multicolumn{3}{|l|}{ Critical control points } \\
\hline \multicolumn{3}{|c|}{ Inadequate cooking and reheating } \\
\hline Incorrect storage & 12 & 57.1 \\
\hline Cross contamination & 5 & 23.8 \\
\hline \multirow[t]{2}{*}{ Infected food handler } & 3 & 14.3 \\
\hline & 1 & 4.8 \\
\hline
\end{tabular}

CHARACTERISTICS OF STUDENTS INVOLVED IN FOOD POISONING OUTBREAKS IN TERENGGANU IN 2016

Table 2 shows the characteristics of students involved in food poisoning episodes in Terengganu. The majority of them $(95.3 \%)$ studied in MOE schools, and $92.1 \%$ of them consumed food from hostel canteens. The distribution of students involved from both urban $(52.6 \%)$ and rural schools $(47.4 \%)$ was almost in equal proportion. Poultry $(46.3 \%)$ was the food consumed the most by students, followed by fish or seafood (27.0\%). Rice or grain (1.2\%) contributed to the least food vehicle related to food poisoning among the students. Forty percent $(n=1037)$ of the students ingested food contaminated with Salmonella spp., followed by Bacillus cereus (36.5\%) and Staphylococcus aureus (23.5\%). Inadequate cooking and reheating contributed to the most important CCPs related to school food poisoning outbreaks. 
TABLE 2. Characteristics of students involved with school food poisoning in Terengganu in year $2016(\mathrm{n}=2589)$

\begin{tabular}{|c|c|c|}
\hline Variables & $\begin{array}{l}\text { No. of student } \\
\text { (n) }\end{array}$ & $\begin{array}{c}\text { Percentage } \\
(\%)\end{array}$ \\
\hline \multicolumn{3}{|l|}{ School category } \\
\hline Ministry of Education & 2463 & 95.1 \\
\hline Non-Ministry of Education & 126 & 4.9 \\
\hline \multicolumn{3}{|l|}{ Students category } \\
\hline Case & 643 & 24.8 \\
\hline Control & 1846 & 75.2 \\
\hline \multicolumn{3}{|l|}{ Premises type } \\
\hline School canteen & 204 & 7.9 \\
\hline Hostel canteen & 2385 & 92.1 \\
\hline \multicolumn{3}{|l|}{ District category } \\
\hline Rural & 1228 & 47.4 \\
\hline Urban & 1361 & 52.6 \\
\hline \multicolumn{3}{|l|}{ Food vehicles } \\
\hline Rice/grain & 30 & 1.2 \\
\hline Eggs & 283 & 10.9 \\
\hline Red Meat & 377 & 14.6 \\
\hline Fish/Seafood & 700 & 27.0 \\
\hline Poultry & 1199 & 46.3 \\
\hline \multicolumn{3}{|l|}{ Microbial agents } \\
\hline Bacillus cereus & 944 & 36.5 \\
\hline Staphylococcus aureus & 609 & 23.5 \\
\hline Salmonella spp. & 1036 & 40.0 \\
\hline \multicolumn{3}{|l|}{ Critical control points } \\
\hline Inadequate cooking and reheating & 1373 & 53.0 \\
\hline Incorrect storage & 585 & 22.6 \\
\hline Cross contamination & 550 & 21.2 \\
\hline Infected food Handler & 81 & 3.1 \\
\hline
\end{tabular}

ASSOCIATED FACTORS AMONG SCHOOLCHILDREN INVOLVED IN SCHOOL FOOD POISONING OUTBREAKS IN TERENGGANU

Table 3 shows a distinct link between the location of a school district and the occurrence of food poisoning episodes. With odds of 1.685 in terms of food poisoning outbreaks, schools in urban areas are more likely to succumb to food poisoning than schools in rural areas. Meanwhile, schools not registered with the MOE are 2.470 times more likely to be associated with a food poisoning outbreak. Students who consume eggs are 4.6 times more likely to be associated with school food poisoning 
compared with those who consume rice or cereals. Cross-contamination $(\mathrm{aOR}=0.445$; 95\% CI: 0.445,0.231; $\mathrm{p}=0.015$ ) is less likely to be linked to school food poisoning compared with inadequate cooking and reheating.

TABLE 3. The associated factors for food poisoning outbreak among schoolchildren in Terengganu year 2016 using Multiple Logistic Regression ( $\mathrm{n}=2589)$

\begin{tabular}{|c|c|c|c|}
\hline Variable & Adjusted OR $(95 \% \mathrm{CI})$ & Wald stat (df) & p-value \\
\hline \multicolumn{4}{|l|}{ District category } \\
\hline Rural & 1 & & \\
\hline Urban & $1.803(1.435,2.267)$ & $25.567(1)$ & $<0.001 *$ \\
\hline \multicolumn{4}{|l|}{ School category } \\
\hline Ministry of Education & 1 & & \\
\hline Non-Ministry of Education & $4.394(2.690,7.177)$ & $34.967(1)$ & $<0.001 *$ \\
\hline \multicolumn{4}{|l|}{ Critical Control Points } \\
\hline Inadequate cooking and reheating & 1 & & \\
\hline Incorrect storage & $0.959(0.743,1.237)$ & $0.104(1)$ & 0.747 \\
\hline Cross contamination & $0.445(0.231,0.856)$ & $5.873(1)$ & $0.015^{*}$ \\
\hline Infected food handler & $0.861(0.507,1.462)$ & $0.307(1)$ & 0.579 \\
\hline \multicolumn{4}{|l|}{ Food vehicle } \\
\hline Rice/grain & 1 & & \\
\hline Egg & $4.627(1.779,12.035)$ & $9.865(1)$ & $0.002 *$ \\
\hline Red Meat & $1.520(0.509,4.536)$ & $0.563(1)$ & 0.453 \\
\hline Fish/Seafood & $2.648(0.757,9.261)$ & $2.325(1)$ & 0.127 \\
\hline Poultry & $1.795(0.543,5.936)$ & $0.919(1)$ & 0.338 \\
\hline
\end{tabular}

Note: *Significant at $\mathrm{p}<0.05$

\section{LOCATION}

Schools in urban districts are more exposed to food poisoning outbreaks. A study conducted in India identified that the general contributing factors to food poisoning in schools are poor canteen layout, inadequate sanitary facilities and unsatisfactory hand hygiene practices among food handlers and schoolchildren (Kar et al. 2018). Cross-contamination involving water in water tanks, undercooked food and the use of untreated water are other contributory factors to school food poisoning outbreaks (Jeffree \& Mihat 2016).
The trend of urbanisation has not only increased the urban population but also brought lifestyles changes. The high cost of living in cities has driven families to seek more sources of income and more wives to work. Hence, these domestic arrangements have caused children to eat at school when their mothers are unable to cook at home because of their busy daily schedules (Ali \& Abdullah 2012). Additionally, food prices may become very high, and children tend to choose cheaper foods that are not nutritious and contain many preservatives and additives 
(Proietti et al. 2014). Additionally, parents may have very limited time to advise their children on food safety and hand hygiene. A study done among parents showed that parents' advice showed a role in improving students' hygiene. Parental influences on food safety awareness had a positive impact on food hygiene practice, which can be easily passed down to their children (Teh et al. 2016).

Most of the urban schools have more students compared with rural schools, so the canteen management will face problems in catering to the high food demands. The canteen condition is an important factor contributing to food poisoning episodes. It is important to plan and develop building infrastructures, such as a school canteen that can cater to clean food services. Proper sewage systems and good canteen conditions without congestion with food items and cooking utensils are also important factors. These factors can lead to an increase in kitchen temperatures, leading to bacterial growth. The proper maintenance of a good sewage and ventilation system is important, as any laxity in this area can lead to the development of ideal breeding grounds for harmful bacteria (Nordin et al. 2016).

The local authority in the urban area is facing several issues. As there are too many schools and factors to be monitored, there may be a presence of immigrant food handlers working in schools. They may not be registered and may not have received any food handling courses or anti-typhoid vaccination. It is shown that food handlers' inadequate knowledge of proper food handling practices may also contribute to school food poisoning outbreaks (Gong et al. 2016). Canteen operators must comply with regulations for them to operate the canteen, and this issue may have been overlooked by the canteen business owner. Enforcement activities are done to ensure they comply with the regulations (local act) before they can operate their food business.

All schoolchildren are vulnerable to food poisoning, as they also have poor knowledge of food safety. It has been demonstrated that even though students with better knowledge have better hygiene practices, they are still reported to practise high-risk behaviour in food choices (Garayoa et al. 2005). Schoolchildren in general tend to have poor knowledge of hand hygiene practices. According to Thailand's global student-based health survey, $15.7 \%$ of Thai students rarely wash their hands before eating (WHO 2017).

\section{SCHOOL CATEGORY}

Non-MOE schools have higher odds of being affected by a food poisoning outbreak because the management of non-registered schools may be lacking in knowledge of what constitutes a proper canteen setup, an appropriate building structure and an effective food hygiene training program for food handlers. The Ministry of Education and the $\mathrm{MOH}$ can make suggestions and plans for training food handlers on food safety measures to prevent the occurrence/recurrence of food poisoning outbreaks.

In a study conducted in Ghana, it was found that children in non-registered schools succumbed to foodborne infections 3 to 12 times per academic year. Food safety management systems were non-existent in non-registered Ghanaian schools, and 23\% of the Ghanaian kitchen staff was not expected to report any occurrence of foodborne infections. Additionally, the poor hygiene associated with $23 \%$ of the Ghanaian kitchen staff in schools makes it unlikely that they would remove their jewellery during the preparation and serving of food in school canteens (Ababio et al. 2016).

\section{FOOD VEHICLES}

In this study, we have found that egg consumption was significantly linked to school food poisoning compared with rice or cereal consumption. During this study, boiled eggs were consumed in egg sandwiches. The CCP was the cross-contamination of eggs with the unsanitary environment. Usually, eggs are associated with $92 \%$ of Salmonella food poisoning. However, in our study, the food poisoning was related to the consumption of eggs contaminated with Bacillus cereus. Salmonella spp. contamination of eggs and eggshells has been identified as a public health concern worldwide. Chicken contaminated through faeces, urates and bedding can vertically transmit Salmonella enteritis to the egg and embryo and cause embryo death due to high bacterial load. Another study carried out in Japan showed that undercooked egg products, as well as salads, rank high on the risk list for food likely to cause food poisoning in schools (Michino \& Otsuki 2000). Unrefrigerated eggs, eggs stored under warm weather conditions and food with raw or undercooked eggs provide ideal conditions for the growth and reproduction of Salmonella spp. (Harun et al. 2015).

In the US, non-typhoidal Salmonella spp. food poisoning accounted for one million cases of food poisoning, 53\% of which stemmed from egg or eggshell contamination (Whiley \& Ross 2015). As such, during the preparation of food for students, caterers can opt to replace eggs with poultry, red meat and rice/grain. However, when the use of eggs is unavoidable, extra food handling precautions need to be observed. 


\section{CRITICAL CONTROL POINTS}

Most of the food poisoning outbreaks in this study were caused by inadequate cooking and reheating (57.1\%). There was a similar finding in an $\mathrm{MOH}$ report, where $50 \%$ of food poisoning outbreaks were caused by improper food handling procedures, such as prolonged handling and inadequate cooking and reheating (MOH 2007). It was found that in the school food poisoning outbreak with known food vehicles, the food was prepared at school canteen premises, and the CCP involved were improper storage, prolonged handling and inadequate cooking and reheating. However, a 24-year (1973-1997) trend of food poisoning in America showed that $57 \%$ of school food poisoning outbreaks were caused by food handler contamination (Daniels et al. 2002).

During our investigations, we found that cross contamination is less likely to be linked to school food poisoning compared with inadequate cooking and reheating. Our study also showed that only $20 \%$ of the school food poisoning outbreaks were related to crosscontamination factor. This finding was different from the Centre for Disease Control and Prevention (CDC) findings, where cross-contamination between food and equipment is considered the main factor in outbreaks (de Oliveira et al. 2014). Food contamination from food handlers is related to workers with pathogens in their bodies and improper personal hygiene practices during food preparation. In our study, where the CCP of infected food handlers was suspected to contribute to food poisoning outbreaks, it was evidenced with positive microbiological analysis of food handlers' hands with Staphylococcus aureus. A study done in Kelantan found hands to be the main culprit for cross-contamination. This occurred because the food handlers were unaware of their hand movements and might have rubbed their face, nose or other body parts. They concluded that there were always possibilities of cross-contamination among food handlers in food handling processes (Zin et al. 2017). Therefore, hand hygiene is the most modifiable factor that can be controlled to prevent food poisoning. It is the most important component that must be highlighted in health promotion programmes in schools. Inappropriate food handling practices, such as using the same cutting board for raw and ready-to-eat food, are potential vehicles for crosscontamination (Carrasco et al. 2012). Similar findings were found in our study, where cross-contamination also occurred during food preparation because of the use of unwashed cooking utensils, the sharing of chopping boards to cut wet and dry ingredients, and poor maintenance of the school canteen.

Inadequately cooking and reheating food can promote bacterial growth, as this CCP fails to kill bacteria.
Additionally, prolonged handling in inappropriate temperatures can increase bacteria replication. Food held for more than $4 \mathrm{~h}$ in the temperature danger zone is unsuitable for human consumption and must be discarded immediately (Abdul-Mutalib et al. 2015). A study done among food handlers in Universiti Putra Malaysia found that food handlers had moderate knowledge of temperature control, cross-contamination, food poisoning and personal hygiene. In the knowledge assessment on temperature control, most of the subjects knew they had to cook food at the minimum cooking temperature, but not all food handlers knew the danger zone of food temperature. Only $73 \%$ of them had used thermometers to measure cooked food temperature, while the rest of them considered bubbles a sign that the food had reached its boiling temperature and was safe for human consumption (Nor-Khaizura et al. 2015).

\section{CONCLUSION}

Schools in urban districts, and the use of eggs in food preparation in school canteens, were factors closely associated with food poisoning episodes among schoolchildren in Terengganu in 2016. However, there are certain limitations in this study as it uses secondary data from the reported food poisoning outbreak report. Many biases biases can occur during case detection, investigation, and report on certain food vehicles and the microbial agents. Additionally, potential confounding effects may be present in this study such as number of meals involved and the age of students that may not reflect the actual relationship between the variables in causing food poisoning outbreak in schools as it may over- or underestimating the impact of independent variable on dependent variable.

To eliminate food poisoning among schoolchildren, it is essential that food handlers be equipped with proper and adequate knowledge of food safety, food handling and hygienic food preparation practices. They also need to be well-informed of the hazard analysis and critical control point (HACCP) concept in food services, and the importance of controlling all the CCPs involved in food preparation. If all the factors mentioned earlier can be properly managed and monitored, food poisoning among schoolchildren can be significantly reduced or prevented.

\section{ACKNOWLEDGEMENTS}

We would like to extend our gratitude to the Director General of Health, Malaysia, for consenting to the release of this article. We would also like to thank the Terengganu state health officers, the Terengganu communicable disease unit, and all Terengganu district health officers 
for their assistance, especially during our efforts to acquire data on food poisoning cases involving school children in Terengganu. Prior to the commencement of this undertaking, ethical approval was obtained from the Malaysian Medical Research and Ethics Committee (MREC), and the ministry of health (MOH), Malaysia. This study was not funded by any organization, and we declare the non-existence of any conflict of interest during the course of our investigations.

\section{REFERENCES}

Ababio, P.F., Taylor, K.D.A., Daramola, B.A. \& Swainson, M. 2016. Food law compliance in developed and developing countries: Comparing school kitchens in Lincolnshire-UK and Ashanti region of Ghana. Food Control 68: 167-173.

Abdul-Mutalib, N., Syafinaz, A., Sakai, K. \& Shirai, Y. 2015. An overview of foodborne illness and food safety in Malaysia. International Food Research Journal 22(3): 896-901.

Ali, N. \& Abdullah, M.A. 2012. The food consumption and eating behaviour of Malaysian urbanites: Issues and concerns. Geografia-Malaysian Journal of Society and Space 8(6): 157-165.

Carrasco, E., Morales-Rueda, A. \& García-Gimeno, R.M. 2012. Cross-contamination and recontamination by Salmonella in foods: A review. Food Research International 45(2): 545-556.

Daniels, N.A., Mackinnon, L., Rowe, S.M., Bean, N.H., Griffin, P.M. \& Mead, P.S. 2002. Foodborne disease outbreaks in United States schools. The Pediatric Infectious Disease Journal 21(7): 623-628.

de Oliveira, A.B.A., da Cunha, D.T., Stedefeldt, E., Capalonga, R., Tondo, E.C. \& Cardoso, M.R.I. 2014. Hygiene and good practices in school meal services: Organic matter on surfaces, microorganisms and health risks. Food Control 40: $120-126$.

Garayoa, R., Cordoba, M., Garcia-Jalon, I., Sanchez-Villegas, A. \& Vitas, A.I. 2005. Relationship between consumer food safety knowledge and reported behavior among students from health sciences in one region of Spain. Journal of Food Protection 68(12): 2631-2636.

Harun, N., Badgujar, V.B., Tan, Y., Othman, N., Ramli, N., Shahabudin, S. \& Zainudin, N. 2015. Poultry chicken eggs: A safe, secure and bacteria free regime in Malaysia. Journal of Health, Population, and Nutrition 29(2): 103.

IPH. 2008. Load of illness. The Third National Health and Morbidity Survey (NHMS III) Malaysia: Ministry of Health. pp. 3-49.

Jeffree, S.M. \& Mihat, O. 2016. Waterborne food poisoning outbreak of Bacillus cereus in primary school Sabah East Malaysia. Journal of Advanced Research in Medicine 3(2\&3): 22-29.

Kar, K., Pradhan, S. \& Samal, B.P. 2018. Morbidity pattern of school children: A study conducted in the urban field practice area of a tertiary health care centre of Odisha, India.
International Journal of Research in Medical Sciences 6(7): 2489-2494.(Kar, 2018 \#138)

Linscott, A.J. 2011. Food-borne illnesses. Clinical Microbiology Newsletter 33(6): 41-45.

Meftahuddin, T. 2002. Review of the trends and causes of food borne outbreaks in Malaysia from 1988 to 1997. The Medical Journal of Malaysia 57(1): 70-79.

Michino, H. \& Otsuki, K. 2000. Risk factors in causing outbreaks of food-borne illness originating in school lunch facilities in Japan. Journal of Veterinary Medical Science 62(5): 557-560.

MOH. 2016. Health Facts 2017 (reference data for 2016). Kuala Lumpur: Ministry of Health.

MOH. 2014. Annual Report 2014. Kuala Lumpur: Ministry of Health. Retrieved from https://www.google.com/search $? \mathrm{q}=$ annual $+\mathrm{moh}+$ report $+2014 \&$ oq $=$ annual + moh + report + 2014\&aqs $=$ chrome. $0.69 \mathrm{i} 59 \mathrm{j} 69 \mathrm{i} 60 \mathrm{j} 014.12526 \mathrm{j} 1 \mathrm{j} 9 \&$ sourceid $=$ chrome \&ie $=$ UTF-8.

MOH. 2009. Food Hygiene Regulations 2009. Kuala Lumpur: Ministry of Health. http://www.fmm.org.my/images/articles/ GS1\%20Malaysia/Presentation\%20FMM\%2 Food\%20 Hygiene.

MOH. 2007. Annual Report 2007. Kuala Lumpur: Ministry of Health. https://www.google.com/search?q=annual + moh + rep ort $+2007 \&$ oq $=$ annual + moh + report $+2007 \&$ aqs $=$ chrome $.69 \mathrm{i}$ 57j013.13092j1j8\&sourceid $=$ chrome\&ie $=U T F-8$.

Nordin, N.H., Razman, M.R. \& Zakaria, S.Z.S. 2016. Ministry of Education on healthy school canteen's management towards quality of life in Malaysia.

Nor-Khaizura, M.A.R., Teoh, C.Y., Sukor, R. \& Nor-Ainy, M. 2015. A case study on knowledge of hygiene among food handlers in Foodservice Complex, Universiti Putra Malaysia. In Hospitality and Tourism 2015: Proceedings of HTC. Malacca, Malaysia: CRC Press. p. 295.

Proietti, I., Frazzoli, C. \& Mantovani, A. 2014. Identification and management of toxicological hazards of street foods in developing countries. Food and Chemical Toxicology 63 : 143-152.

Salleh, W., Lani, M.N., Abdullah, W.Z.W., Chilek, T.Z.T. \& Hassan, Z. 2017. A review on incidences of foodborne diseases and interventions for a better national food safety system in Malaysia. Malaysian Applied Biology 46(3): 1-7.

Soon, J., Singh, H. \& Baines, R. 2011. Foodborne diseases in Malaysia: A review. Food Control 22(6): 823-830.

Teh, N.S.A., Ab Hamid, M.R., Mohd Asmawi, U.M. \& Md Nor, N. 2016. Food hygiene's knowledge, attitudes and practices between urban and suburban adolescents. ProcediaSocial and Behavioral Sciences 234: 36-44.

Weaver, E.R., Agius, P.A., Veale, H., Dorning, K., Hlang, T.T., Aung, P.P., Fowkes, F.J. \& Hellard, M.E. 2016. Water, sanitation, and hygiene facilities and hygiene practices associated with diarrhea and vomiting in monastic schools, Myanmar. The American Journal of Tropical Medicine and Hygiene 95(2): 278-287.

Whiley, H. \& Ross, K. 2015. Salmonella and eggs: From production to plate. International Journal of Environmental Research and Public Health 12(3): 2543-2556. 
WHO. 2017. Thailand 2015 Global School - Based Student Health Survey. Bangkok: World Health Organization.

WHO. 2015. WHO Estimates of the Global Burden of Foodborne Diseases: Foodborne Disease Burden Epidemiology Reference Group 2007-2015. Geneva: World Health Organization.

Zin, M., Auzureen, A., Aklilu, E., Goriman Khan, M.A.K., Hamdan, R., Ibrahim, A.S.I. \& Soon, J.M. 2017. Microbiological quality of cooked meat products sold in Kelantan, Malaysia during Ramadhan month. International Food Research Journal 24(1): 414-421.
Department of Community Medicine

School of Medical Sciences

Health Campus, Universiti Sains Malaysia

16150, Kubang Kerian, Kelantan Darul Naim Malaysia

*Corresponding author; email: afilza@usm.my

Received: 24 December 2019

Accepted: 21 September 2020 